JOTE Volume 2 Nomor 1 Tahun 2020 Halaman 82-93 JOURNAL ON TEACHER EDUCATION

Research \& Learning in Faculty of Education

\title{
PENINGKATAN KERJASAMA MELALUI METODE OUTBOUND PADA ANAK KELOMPOK A RA MUADZ BIN JABAL DESA SAWAH KAMPAR UTARA
}

\author{
Jenny Amelia ${ }^{(1)}$, Musnar Indra Daulay ${ }^{(2)}$, Rizki Amalia, ${ }^{(3)}$ \\ Program Studi Pendidikan Guru Pendidikan Anak Usia Dini, \\ Fakultas IImu Pendidikan, Universitas Pahlawan Tuanku Tambusai \\ Email : JennyAmelia0506@gmail.com
}

\begin{abstract}
Abstrak
Penelitian ini bertujuan untuk mengetahu pelaksanaan pada kegiatan outbound dalam meningkatkan kemampuan kerjasama dan peningkatan kemampuan kerjasama kelompok A RA Muadz bin Jabal Desa Sawah Kampar Utara. Metode yang digunakan adalah Penelitian Tindakan Kelas (PTK) dengan model KurtLewin. Penelitian ini terdiri dari prasiklus, siklus I, siklus II. Pada siklus dan siklus I terdiri dari 4 tahap pengumpulan data dan pada penelitian ini menggunakan teknik obesrvasi, wawancara, dan dokumentasi. Hasil penelitian ini adalah Peningkatan kemampuan kerjasama dari hasil pra siklus menuju siklus II mencapai 100\%. Dapat dilihat dari prasiklus terdiri 20 anak dalam satu kelas, diketahui bahwa 1 anak mendapat skor BSB (5\%), tidak ada anak yang mendapat skor BSH (0\%), dan 6 anak mendapat skor MB (30\%), dan 13 anak mendapat skor BB (65\%) jumlah penilaian dari 20 anak adalah 768,75 sedangkan nila rata- rata adalah 38,43 dan siklus I dari 20 anak, diketahui bahwa 7 anak mendapat skor BSB (35\%), 13 anak mendapat skor BSH (65\%), dan tidak ada anak mendapat skor MB (0\%), dan tidak ada anak mendapatskor BB (0\%) jumlah penilaian dari 20 siswa adalah 1487,5 sedangkan nilai rata-rata adalah 74,375, sedangkan pada siklus II : 20 anak yang mendapat skor BSB (100\%), tidak ada anak mendapat skor BSH $(0 \%)$, tidak ada anak mendapat skor MB $(0 \%)$, tidak ada anak mendapat skor BB $(0 \%)$.
\end{abstract}

Kata kunci: Metode Outbound, kerjasama anak.

\section{Abstract}

This study aims to determine the implementation of outbound activities in increasing the ability of cooperation and increasing the ability of group A RA Muadz bin Jabal, Sawah Kampar Utara Village. The method used was Classroom Action Research (PTK) with the KurtLewin model. This research consisted of pre-cycle, cycle I, cycle II. In cycle and cycle I consisted of 4 stages of data collection and in this study using observation techniques, interviews, and documentation. The results of this study are an increase in the ability of cooperation from the results of the pre cycle to cycle II reaches $100 \%$. It can be seen from the pre-cycle consisting of 20 children in one class, it is known that 1 child got a BSB score (5\%), no child got a BSH score $(0 \%)$, and 6 children got an MB score (30\%), and 13 children got a BB score $(65 \%)$ The total score of 20 children was 768.75 while the average score was 38.43 and the first cycle of 20 children, it is known that 7 children got a BSB score (35\%), 13 children got a BSH 
score $(65 \%)$, and no child got an MB score $(0 \%)$, and no child got a BB score $(0 \%)$, the number of assessments from 20 students was 1487.5 while the average score was 74.375, while in cycle II: 20 children were got a BSB score $(100 \%)$, no child got a BSH score $(0 \%)$, no child got an MB score $(0 \%)$, no child got a BB score $(0 \%)$.

Keywords: Outbound method, children's cooperation.

\section{PENDAHULUAN}

Kerjasama merupakan salah satu fitrah manusia sebagai makhluk sosial. Semakin modern seseorang maka ia akan semakin banyak bekerjasama dengan orang lain, bahkan seakan tanpa dibatasi oleh ruang dan waktu tentunya dengan perangkat yang modern pula. Menurut Poerwadarminta (2007:578) kerjasama merupakan perbuatan yang saling bantu-membantu, tolong menolong atau yang dilakukan secara bersama-sama untuk mencapai suatu perbuatan.

Outbound adalah sebuah proses dimana seseorang mendapatkan pengetahuan, keterampilan dan nilai-nilainya langsung dari pengalaman memunculkan sikap-sikap saling mendukung, komitmen, rasa puas dan memikirkan masa yang akan datang yang sekarang tidak diperoleh melalui metode belajar yang lain (Maryatun, 2010:2).

Dalam kegiatan berkaitan dengan meningkatkan kemampuan kerjasama merupakan kegiatan outbound. Sesuai dengan pendapat salah satu guru, sekolah tersebut memerlukan suatu kegiatan yang dapat melatih kemampuan kerjasama anak. Tujuan dari kegiatan outbound untuk meningkatkan kemampuan kerjasama yang dapat menekan pada masa selanjutnya. Di antara bentuk kegiatan oubound adalah untuk membentuk karakter sosial anak.

Dari hasil observasi di RA. Muadz Bin Jabal paada saat dikelas anakanak diberikan guru tugas kelompok untuk memasukkan bola dalam keranjang sesuai dengan warnanya. Terlihat anak-anak tidak saling membantu satu sama lainnya, anak lebih mementingkan dirinya sendiri dalam menggelompokkan bola dan tidak ingin membantu teman yang kesulitan untuk memasukkan bola dalam keranjang. Begitu juga dengan kurangnya komunikasi diantara anak-anak dalam satu kelompok dan kekompakan anak juga tidak terjalin dengan baik sesama anak dalam kelompok. Dari 20 orang anak dalam satu kelas hanya 13 orang anak yang belum berkembang kerjasamanya, 6 orang mulai berkembang kerjasamanya, dan 1 orang berkembang sangat baik kerjasmanya.

Identifikasi masalah Kurangnya sikap toleran dalam kerjasama dengan kelompok, Kurangnya sikap saling membantu sesama teman, Rendahnya rasa memahami sesama teman, Kurangnya kekompakan dalam kelompok.

Rumusan masalah Bagaimana pelaksanaan kegiatan outbound dalam Peningkatan Kerjasama Melalui Metode outbound Pada Anak Kelompok A R Muadz Bin Jabal Desa Sawah Kampar Utara?, Bagaimana peningkatan kemampuan kerjasama kelompok A RA Muadz Bin Jabal Desa Sawah Kampar Utara? 
Tujuan penelitian Untuk mengetahui pelaksanaan kegiatan outbound dalam peningkatkan kemampuankerjasam, Untuk mengetahui peningkatan kemampuan kerjasama kelompok ARA Muadz Bin Jabal.

Berdasarkan uraian latar belakang di atas maka peneliti bermaksud memperbaiki proses pembelajaran kerjasama melalui kegiatan outbound. Dengan outbound anak bisa belajar untuk berkomunikasi secara baik sesama temannya dan dapat bekerja sama dalam satu kelompok. Dari uraian tersebut maka penulis tertarik untuk mengadakan penelitian dengan judul "Peningkatan Kerjasama Melalui Metode outbound Pada Anak Kelompok A RA Muadz Bin Jabal Desa Sawah Kampar Utara"

\section{METODE}

Metode penelitian yang digunakan oleh penulis yaitu penelitian tindakan kelas. Penelitian tindakan kelas pertama kali oleh Kurtlewin tahun 1946 seorang ahli psikologi social dari Amerika, yang sampai saat ini masih berkembang. Penelitian Tindakan Kelas (PTK) di RA Muadz Bin Jabal Desa Sawah Kampar Utara yang berupaya memberikan gambaran secara sistematis dan akurat, serta dapat mengungkapkan adanya peningkatan kemampuan kerjasama anak usia 4-5 tahun melalui metode outbound. Subyek dalam penelitian ini adalah siswa-siswi kelompok A RA Muadz Bin Jabal yang terdiri dari laki-laki 11 orang dan perempuan 9 orang sehingga jumlah keseluruhannya ada 20 siswa dalam satukelas.

Teknik pengumpulan data dalam penelitian tindakan kelas ini dapat menggunakan beberapa teknik dalam pengumpulan data, antara lain sebagai berikut:

a) Wawancara merupakan metode pengumpulan data yang untuk memberikan beberapa pertanyaan secara lisan kepada seorang atau subyek yang diteliti. Peneliti mengadakan wawancara dengan guru kelas kelompok A yang bernama lbu Nurfitrianis, S.Pd.

b) Observasi merupakan kegiatan mengamati untuk mendapatkan data secara sengaja, sistematis mengenai fenomena dengan gejala-gejala psikis untuk kemudian dilakukan pencatatan ( Subagyo, 2006 : 62).

Tabel 1.

Jenis permainan setiap indikator

\begin{tabular}{|c|c|c|}
\hline Variabel & Indikator & Jenis permainan \\
\hline \multirow{4}{*}{$\begin{array}{l}\text { Kemampuan } \\
\text { kerjasama }\end{array}$} & $\begin{array}{l}\text { Menunjukkan sikap toleran } \\
\text { dapat bekerjasama dengan } \\
\text { kelompok }\end{array}$ & $\begin{array}{l}\text { Memasukkan bola kedalam } \\
\text { Keranjang }\end{array}$ \\
\hline & $\begin{array}{l}\text { Saling membantu sesama } \\
\text { teman }\end{array}$ & Estafet karung \\
\hline & $\begin{array}{l}\text { Kekompakan dalam } \\
\text { kelompok }\end{array}$ & Bakiak \\
\hline & $\begin{array}{l}\text { Saling memahami sesama } \\
\text { teman }\end{array}$ & $\begin{array}{l}\text { Lompat tali karet } \\
\text { gelang }\end{array}$ \\
\hline
\end{tabular}


c) Dokumentasi dalam penelitian ini digunakan untuk mengumpulkan data-data foto serta rencana pelaksanaan kegiatan outbound meningkatkan kemampuan kerjassama yang bertujuan menunjang hasil penelitian anak pada kelompok A di RA Muadz Bin Jabal.

\section{Instrumen Penelitian}

Metode pengumpulan data yang dipakai dalam penelitian ini menggunakan observasi Melalui metode observasi peneliti mengamati langsung perilaku anak setelah diberikan tindakan. Dalam penelitian ini, peneliti menggunakan Aspek yang diamati dalam penelitian ini kemampuan kerjasama anak. Penelitian ini menggunakan instrument yang terdapat pada Tabel berikut ini:

Tabel 2.

Rubrik Penilaian Kemampuan Kerjasama

\begin{tabular}{|c|c|c|c|c|}
\hline No & Indikator & $\begin{array}{l}\text { Kinerja } \\
\text { Penilaia } \\
\mathbf{n}\end{array}$ & skor & Deskripsi \\
\hline \multirow{4}{*}{1.} & \multirow{4}{*}{$\begin{array}{c}\text { Menunjukkan } \\
\text { sikap toleran } \\
\text { dapat bekerja } \\
\text { sama dengan } \\
\text { kelompok }\end{array}$} & BSB & 4 & $\begin{array}{l}\text { Anak mampu bekerjasama } \\
\text { dengan kelompok sesuai } \\
\text { dengan tugasnya. }\end{array}$ \\
\hline & & BSH & 3 & $\begin{array}{l}\text { Anak mampu bekerjasama } \\
\text { dengan kelompok. }\end{array}$ \\
\hline & & MB & 2 & $\begin{array}{l}\text { Anak mampu bekerjasama } \\
\text { dengan kelompok sesuai tugas } \\
\text { dengan perintah guru. }\end{array}$ \\
\hline & & BB & 1 & $\begin{array}{l}\text { Anak tidak mampu } \\
\text { bekerjasama dengan kelompok. }\end{array}$ \\
\hline \multirow{4}{*}{2.} & \multirow{4}{*}{$\begin{array}{l}\text { Saling } \\
\text { membantu } \\
\text { sesama } \\
\text { teman }\end{array}$} & BSB & 4 & $\begin{array}{l}\text { Anak mampu membantu } \\
\text { sesama teman sesuai dengan } \\
\text { tugas. }\end{array}$ \\
\hline & & $\mathrm{BSH}$ & 3 & $\begin{array}{l}\text { Anak mampu membantu } \\
\text { sesama teman. }\end{array}$ \\
\hline & & MB & 2 & $\begin{array}{l}\text { Anak mampu membantu } \\
\text { sesama teman dengan printah } \\
\text { guru. }\end{array}$ \\
\hline & & BB & 1 & $\begin{array}{l}\text { Anak tidak mampu membantu } \\
\text { sesama teman. }\end{array}$ \\
\hline \multirow{4}{*}{3.} & \multirow{4}{*}{$\begin{array}{l}\text { Kekompakan } \\
\text { dalam } \\
\text { kelompok. }\end{array}$} & BSB & 4 & $\begin{array}{l}\text { Anak mampu menunjukkan } \\
\text { kekompakan dalam kelompok } \\
\text { sesuai dengan tugasnya. }\end{array}$ \\
\hline & & $\mathrm{BSH}$ & 3 & $\begin{array}{l}\text { Anak mampu menunjukkan } \\
\text { kekompakan dalam kelompok. }\end{array}$ \\
\hline & & MB & 2 & $\begin{array}{l}\text { Anak mampu menunjukkan } \\
\text { kekompakan dalam kelompok } \\
\text { dengan printah guru. }\end{array}$ \\
\hline & & BB & 1 & $\begin{array}{l}\text { Anak tidak mampu } \\
\text { menunjukkan kekompakan } \\
\text { dalam kelompok. }\end{array}$ \\
\hline 4. & Saling & BSB & 4 & Anak mampu memahami \\
\hline
\end{tabular}




\begin{tabular}{|c|c|c|c|l|}
\hline \multirow{2}{*}{$\begin{array}{c}\text { memahami } \\
\text { sesama } \\
\text { teman }\end{array}$} & BSH & 3 & $\begin{array}{l}\text { sesama teman sesuai dengan } \\
\text { tugasnya. }\end{array}$ \\
\cline { 3 - 4 } & MB & 2 & $\begin{array}{l}\text { Anak mampu memahama ma meman } \\
\text { sesama teman dengan printah } \\
\text { guru. }\end{array}$ \\
\cline { 2 - 4 } & BB & 1 & $\begin{array}{l}\text { Anak tidak mampu memahami } \\
\text { sesama teman }\end{array}$ \\
\cline { 2 - 4 } & &
\end{tabular}

\section{HASIL PENELITIAN DAN PEMBAHASAN}

\section{A. Deskripsi Pratindakan}

Pelaksanaan penelitian ini bertempat di RA. Muadz Bin Jabal Desa Sawah Kampar Utara pada anak kelompok A. Pembelajaran yang ada disekolah ini menoton hanya didalam kelas saja menggunakan majalan anak. Anak setiap hari menggunakan majala sehingga anak hanya terfokus pada dirinya sendiri dan tidak memperdulikan temannya. Saat peneliti melakukan observasi di RA Muadz Bin Jabal peneliti menemukan 13 orang anak belum berkembang kerjasamanya, 6 orang anak mulai berkembang kerja samanya, dan 1 orang anak berkembang sangat baik kerja samanya.

RA Muadz Bin Jabal terletak di Desa Sawah yang tidak jauh dari pemukiman warga, akan tetapi sekolah RA. Muadz Bin Jabal ini memiliki lapangan yang bagus serta lingkungan yang asri. Keasrian alam sekitar sekolah Ra Muadz Bin Jabal ini lah yang menjadi daya tarik tersendiri bagi sekolah, yang mana anak dapat belajar dengan tenang tanpa adanya riuh kendaraan. Hamparan rumput nan hijau membuat peneliti ingin menggunakan metode outbound. Dalam penelitian ini yang menjadi objek penelitian adalah kelompok $A$ dengan jumlah anak sebanyak 20 anak, yang terdiri dari 11 anak laki laki dan 9 anak perempuan. Observasi dilakukan terhadap 2 aspek yaitu:

1. Pelaksanaan kegiatan outbound dalam peningkatan kemampuan kerjasama.

2. Peningkatan kemampuan kerajsama kelompok A RA Muadz Bin Jabal.

Dalam penelitian ini peneliti menerapkan metode outbound untuk meningaktkan kemampuan kerjasama anak kelompok A RA. Muadz Bin Jabal Desa Sawah Kampar Utara yang selama ini menunjukkan kemampuan anak tergolong belum berkembang. Untuk itu perlu dilakukan suatu tindakan dengan penerapan metode outbound. Dengan menggunakan Metode Outbound anakanak lebih bersemangat dalam belajar serta anak mampu mengenali dan memahami dirinya sendiri begitu juga dengan teman-temannya.

\section{B. Deskripsi Hasil Tindakan Tiap Siklus}

\section{SIKLUS I}

\section{a. Pertemuan Pertama Siklus I}

\section{a) Perencanaan}

Pertemuan pertama siklus I dilaksanakan pada hari selasa tanggal 7 Maret 2020. Pada tahap perencanaan guru menyiapkan rencana pelaksanaan pembelajaran harian (RPPH), menyediakan media gambar 
tentang tempa-tempat rekreasi dan alat bahan untuk kegiatan outbound, dan menyusun instrumen observasi aktivitas guru dan anak. Perencanaan yang telah dibuat bertujuan untuk digunakan pada tahap pelaksanaan. Semua perencanaan yang telah dibuat terlampir padalampiran.

\section{b) Pelaksanaan}

Pada tanggal 7 Maret 2020 merupakan minggu ke 12 pada kegiatan belajar mengajar semester genap. Kegiatan yang dilakukan anak yaitu berbaris dilapangan terbuka yang berada di depan sekolah, kemuadian anak diajak oleh guru untuk berdoa dan bernyanyi.

c) Pengamatan(Observasi)

Pada hasil pengamatan, terdapat anak yang masih belum melakukan kerjasama dengan baik. Masih terdapat anak yang egois dan pemalu. Sehingga dalam hal ini perlu dilakukan evaluasi. Selain itu pada kegiatan awal anak masih banyak yang kurang semangat. Selain itu, suara guru harus lebih keras lagi dalam memberikan instruksi kepada anak agar mudah dipahami. Untuk lebih jelasnya terdapat beberapa aspek pengamatan berdasakan aktivitas anak dan guru dengan format Cheklist.

\section{SiklusII}

\section{a. Pertemuan Pertama Pada Siklus II}

\section{a) Perencanaan}

Pertemuan pertama siklus II dilaksanakan pada hari Senen tanggal 15 Juni 2020. Pada tahap perencanaan guru menyiapkan rencana pelaksanaan pembelajaran harian (RPPH), menyediakan media, dan menyusun instrumen observasi aktivitas guru dan anak. Perencanaan yang telah dibuat bertujuan untuk digunakan pada tahap pelaksanaan.

\section{b) Pelaksanaan}

Pada tanggal 15 Juni 2020 merupakan minggu ke 22 pada saat ini anak datang ke sekolah untuk mengikuti rapat kelulusan, disaat orang tua rapat anak-anak diperintahkan untuk dihalaman Kemudian anak-anak melakukan kegiatan outbound.

\section{c) Observasi (Pengamatan)}

Pada hasil pengamatan, terdapat anak tidak maumengalah dalam bermain bakiak sehingga terjadi pertengakaran dan ada yang menangis. Anak sudah mulai dapat melatih kerjasama dengan kelompok, setelah selesai setiap kegiatan akhir peneliti memberikan pertanyaan seputar permainan tadi. Selain itu pengamatan aktivitas guru dan anak bisa dilihat dalamlampiran.

\section{d) Refleksi}

Dari hasil observasi diatas, sehingga dapat dievaluasi terkait cara instruksi anak yang bermain agar lebih bersabar dalam menunggugiliran. Sehingga guru harus lebih memperhatikan mana anak yang curang dan tidak.

\section{Nilai Kemampuan Kerjasama}

Untuk mengetahui bagaimana kemampuan kerjasama anak, peneliti menilai dengan cara mengobservasi anak dan guru melakukan kegiatan pembelajran dengan metode berkelompok. Setalah dilakukan adanya metode berkelompok guru memberikan tugas terkait dengan peningkatan kemampuan 
kerjasama anak yaitu dengan melakukan pembelajaran yang sesuai dengan tema hariini.

Keterangan Indikator di atas adalah Sikap toleran dapat bekerjasama dengan kelompok (indikator 1), Saling membantu dengan teman (indikator 2), Kekompakan dalam kelompok (indikator 3), Saling memahami sesama teman (indikator 4). Sedangkan untuk keterangan kategori adalah BB (Belum Berkembang), MB (Mulai Berkembang), BSH (Berkembang Sesuai Harapan), dan BSB (Berkembang Sangat Baik).

Dari prasiklus dapat diketahui bahwa dari 20 Anak dalam satu kelas, diketahui bahwa 1 Anak mendapat skor BSB (5\%), Tidak ada anak yang mendapat skor BSH (0\%), dan 6 Anak mendapat skor MB (30\%), dan 13 Anak mendapat skor BB (65\%). Data pra siklus di atas diketahui bahwa jumlah penilaian dari 20 Anak adalah 768,75 sedangkan nilai rata-rata adalah 38,43. Setalah penilaian pra siklus dilakukan, kemudian siklus I dijalankan dan diketahui berapa hasilnya dari 20 anak dalam satu kelas, diketahui bahwa 7 anak mendapat skor BSB (35\%), 13 anak mendapat skor BSH (65\%), dan tidak ada anak mendapat skor MB, dan tidak ada anak mendapat skor BB. Dari data diatas dikatahui bahwa jumlah penilaian 20 orang anak adalah 1487,5 sedangkan rata-ratanya adalah 74,375.

Dari data siklus II dapat diketahui bahwa dari 20 anak dalam satu kelas, diketahui bahwa 20 anak mendapat skor BSB (100\%), tidak ada anak mendapat skor $\mathrm{BSH}(0 \%)$, dan tidak ada anak mendapat skor $\mathrm{MB}(0 \%)$, dan tidak anak mendapat skor BB (0\%). Data siklus II di atas diketahui bahwa jumlah penilaian dari 20 anak adalah 1875 sedangkan nilai rata-rataadalah 93,75 yang dikategorikan dalam skor BSB (Berkembang Sangat Baik) sehingga sudah adanya peningkatan pada nilai rata-rata perkembangan kemampuan kerjasama anak.

\section{Perbandingan Hasil Tindakan Antar Siklus}

Prasiklus dimana belum dilakukannya kegiatan outbond, anak masih belum bisa melakukan kerjasama dengan baik antar anak didalam kelas. Anak masih belajar menoton didalam kelas sehingga anak tidak berkembang dengan baik. Anak hanya belajar menggunakan lembar kerja yang mana anak tidak memiliki rasa kebersamaan karena anak hanya terfokus pada lembar kerja masing-masing. Dengan adanya metode outbound anak dapat merasakan suasana baru dan tidak membosankan.

Pada siklus I anak suda bisa bekerja sama karena anak merasa sangat senang dengan permainan tradisional yang dilakukan dihalaman terbuka, sehingga dapat merangsang kerjasama anak dalam kelompok. Anak juga menikmati suasana belajar diluar kelas. Anak juga cepat mempelajari dan menjalankan perintah guru, walaupun sebelumnya anak masih ada rasa canggung tetapi karena permainanya sangat menarik dapat menghilangkan rasa takut serta canggung seorang anak.

Dapat dilihat dari hasil kemampuan dan ketuntasan kerjasama anak. Pada pra siklus jumlah nilai ke 20 anak sebesar 768,75 dengan rata-rata 38,43 dikategorikan anak belum berkembang (BB). Setelah itu anak mengalami 
peningkatan pada siklus I yang jumlah nilainya 1487,5 dengan rata-rata 74,375 dikategorikan anak berkembang sesuai harapan (BSH). Dan mengalami peningkatan lagi di siklus II yang jumlah nilainya 1875 dengan rata-rata 93,75. Yang dikategorikan anak berkembang sangat baik (BSH). Perkembangan kerjasama anak melalui metode outbound diperkuat lagi dengan data grafik dibawah ini:

\section{Grafik 3.}

Hasil Kemampuan Dan ketuntasan Kerjasama Anak Pra Siklus, Siaklus I, dan Siklus II

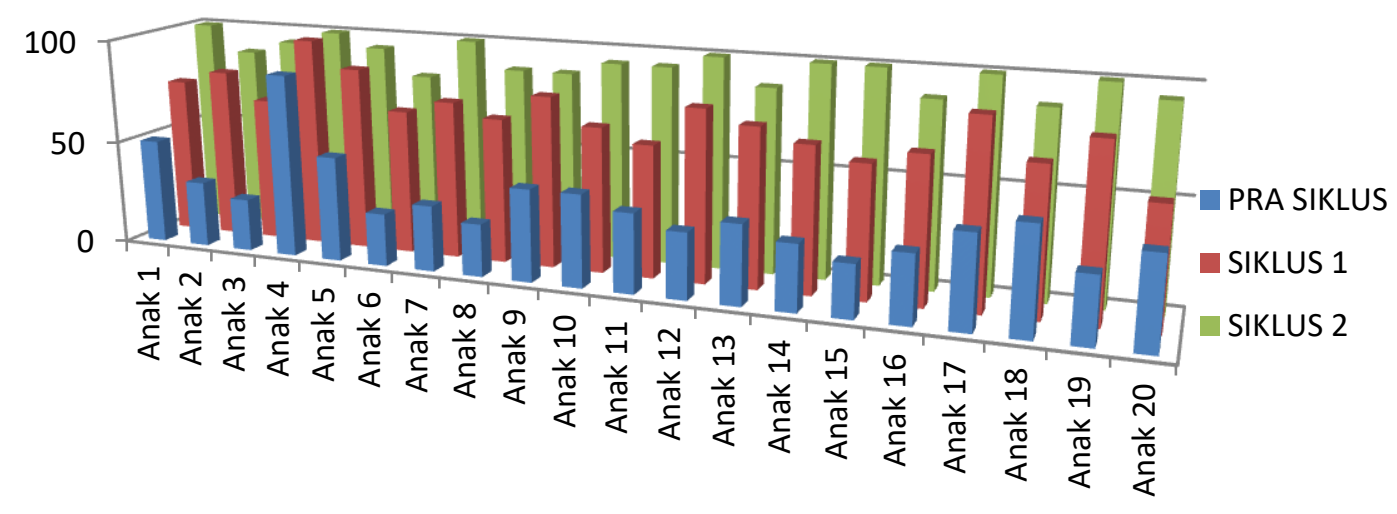

Sumber : Data Peneliti.

Dari data grafik diatas dapat dilihat kerjasama anak pada kegiatan outbound mengalami peningkatan persiklusnya. Dapat disimpulkan bahwah menggunakan metode outbound dapat meningkatkan kerjasama pada anak kelompok A RA Muadz Bin Jabal Desa Sawah Kampar Utara.

\section{PEMBAHASAN}

\section{a. Pelaksanaan Kegiatan Outbound dalam Meningkatkan Kemampuan Kerjasama Anak KelompokA}

RA Muadz Bin Jabal adalah salah satu sekolah yang berlokasikan di desa sawah kampar utara yang berada di bawah yayasan Muadz Bin Jabal dan di ketuai oleh H. Drs. M. Yunus, MM. Pembelajaran di RA Muadz Bin Jabal terkait kemampuan kerjasama dengan menggunakan pembelajaran yang monoton yaitu dengan melakukan bermain secara berkelompok di dalam kelas, belum menggunakan pembelajaran di luar kelas. Selain itu kegiatan outbound yang dilakukan di luar kelas guna untuk meningkatkan kemampuan kerja sama anak agar anak mampu melakukan kerjasama dengan teman sebaya sesuai dengan keadaan yang ada disekitar. Berhubungan dengan keasrian alam sekitar dan halaman yang luas sehingga dalam penelitian ini peneliti menerapkan peningkatan kemampuan kerja sama anak RA Muadz Bin Jabal yang kebetulan merupakan pembelajaran di luar kelas. Dijelaskan dalam teori yang diungkapkan oleh Ahmad Susanto dalam buku perkembangan anak usia dini tentang tahapan dalam bekerjasama dijelaskan bahwa kegiatan atau suasana diluar kelas yang tidak membosankan menjadikan suasana pada proses belajar mengajar asyik dan nyaman untuk anak, dan didukung dengan penggunaan kegiatan pembelajaran yang bervariasi. 
Mengembangkan kemampuan kerjasama pada anak usia dini lebih mudah jika menggunakan kegiatan yang menarik dan membuat anak bersemangat yang memudahkan anak dalam memahami atau menguasai suatu materi pembelajaran. Media merupakan suatu alat yang digunakan sebagai perantara atau pengantar yang membawa informasi pelajaran yang bertujuan memudahkan mencapai tujuan pembelajaran. Oleh karena itu, media sangat diperlukan dalam pembelajaran.

Pada dasarnya anak usia dini lebih mudah untuk pembentukan kehidupan bersosialisasi. Jika tidak ada pertukaran pendapat dan saling menolong dengan sesama maka pembelajaran di dalam kelas itu akan menjadipasif. Dari sini dapat menyimpulkan bahwa peningkatan kerjasama dapat dilakukan dengan kegiatan yang bersangkutan dengan secara kelompok. Kegiatain outbound yang dilakukan di luar kelas, melatih untuk anak dapat melakukan kegiatan yang secara berkelompok dan menujukkan bahwa hidup masih membutuhkan bantuan orang lain. Kegiatan outbound ini menstimulus anak agar dapat memahami sifat dan sikap antar kelompok.

Pelaksanaan kegiatan outbound memiliki banyak manfaat, disamping anak bersemangat dalam belajar, kegiatan outbound juga mampu melatih anak dalam motorik kasar yang dilakukan dengan cara lomba bakiak. Selain itu manfaat untuk guru yaitu menjadikan anak lebih bersemangat, memudahkan anak dalam memahami peningkatan kemampuan kerjasama, dan membuat anak tertarik karena kegiatan tersebut tidak dilakukan setiap hari guna untuk merefresh semangat anak- anak. Selain itu, dalam penggunaan berkelompok kegiatan oubound juga mampu memberikan interaksi dalam melakukan suatu permainan yang berkelompok untuk bekerja sama.

Pelaksanaan kegiatan outbound dalam penelitian tindakan kelas ini dapat meningkatkan kemampuan kerjasama pada anak kelompok A RA Muadz Bin Jabal dibuktikan dengan cara pelaksanaan kegiatan outbound yang dilakuakn di halaman sekolah dengan lingkungan yang asri serta halaman yang luas membuat anak menjadi leluasa dalam bergerak dan tidak membosankan. Hal ini dibuktikan dengan anak yang mulaitertarik dengan pelaksanaan kegiatan outbound yang kemudian dilakukan secara permainan dengan lomba dalam artian setiap kelompokakan bersaing untuk mendapatkan banyak poin.

Pelaksanaan kegiatan outbound mampu membuatan anak asik dan senang, hal ini dibuktikan pula dengan antusias anak dalam berlomba- lomba dengan permainan zaman dahulu. Dalam permainan zaman dahulu guna untuk mengingatkan anak-anak bahwa permainan tradisional perludi budidayakan agar tidak selalu bergantung pada gadget. Selain dengan adanya manfaat permainan tradisional, anak-anak dirumah dapat memainkannya dengan teman sebaya.

Kegiatan outbound dengan menggunakan permainan tradisional untuk melestarikan budaya yang dulunya ditinggalkan oleh nenek moyang dan di wariskan untuk anak-anak. Pelaksanaan kegiatan outbound setiap siklus sama permainanya, siklus I adalah anak boleh memilih permainan mana yang akan dimainkan sedangkan pada siklus II anak harus memainkan semua permainan 
yang telah disediakan pada outbound karena anak telah memahami dan mengerti akan aturan main.

Dalam peningkatan kemampuan kerjasama menggunakan empat (4) indikator menunjukkan sikap toleran dapat bekerjasama dengan kelompok, saling membantu sesama teman, saling memahami sesama teman,dan kekompakan dalam kelompok. Pada pra siklus, siklus I dansikulusll terdapat nilai kemampuan sesuai indicator yang terlampir.Siklus I dan sikus II yang membedakan adalah kemampuan anak. Jadi, dapat disimpulkan bahwa pelaksanaan kegiatan outbound yang dilakukan pada anak kelompokA RA Muadz Bin Jabal memberikan peningkatan terkait kemajuan kerja sama dibuktikan dengan cara anak memasukkan bola kedalam keranjang, estafet karung, bakiak, lompat tali karet gelang.

\section{b. Peningkatan Kemampuan Kerjasama Kelompok a Melalui Kegiatan OUTBOUND}

Dalam peningkatan kemampuan kerjasama memalui kegiatan outbound secara kelompok disimpulkan bahwa peningkatan kemampuankerjasama anak meningkat. Pada Pra Siklus sebesar 5\% dan siklus I hasil persentase sebesar 35\% hingga meningkat pada siklus II sebesar100\%

Pada kegiatan inti siklus I, anak bernama Dinda dan Ali sangat tidak mau diam, dan usil mengganggu temannya. Saat guru menjelaskan, kedua anak tersebut bermain sendiri dengan sesuka hatinya. Namun, ketika ditunjuk untuk melakukan sebuah permainan, keduanya belum mampu melakukannya. Disamping itu, pada saat berkelompok kedua anak tersebut mengganggu temannya lagi, bahkan mencubittemannya. Peneliti kembali melakukan observasi dan refleksi agar anak bisa menyatu dengan teman-mannya saat bermain. Peneliti mengambil kebijakan untuk membagi anak tersebut ke dalam kelompok yang berbeda.

Pada siklus II anak suda mampu bekerjasama dengan sangat baik, yang mana anak menikmati setiap permainan dan mengalami peningkatan kekompakan, saling tolong menolong, memahami sesama teman sessuai dengan yanga da di indikator. Jadi, dapat disimpulkan bahwa kerjasama anak meningkat menggunakan metode outbound pada anak kelompok A RA Muadz Bin Jabal Desa Sawah Kampar Utara. Peningkatan tersebut antara lain sebagai berikut:

1. Hasil pra siklus menunjukkan bahwa anak yang sesuai pada kategori penilaian mencapai persentase sebesar5\% Hasil siklus I menunjukkan bahwa pada kategori penilaian hasil kegiatan outbound mencapai persentase sebesar 35\%

2. Hasil siklus II menunjukkan bahwa pada kategori penilaian mencapai persentase sebesar $100 \%$.

\section{SIMPULAN}

Berdasarkan pada hasil analisis penelitian, maka dapat diambil kesimpulan sebagai berikut: Pelaksanaan kegiatan outbound dalam meningkatkan kemampuan kerjasama kelompok A RA Muadz Bin Jabal pada 
siklus I dan siklus II memainkan beberapa permainan yaitu, permainan memasukkan bola dalam keranjang, estafet karung, bakiak, lompat tali karet gelang . Pada siklus I sama dengan siklus II. Dalam hal ini kegiatan outbound mampu meningkatkan kemampuan kerjasmaanak.

PeningkatankemampuankerjasamakelompokA RA. Muadz Bin Jabal dalam kegiatan outbound yang sudah dilakukan peningkatan kemampuan kerjasama pada anak terbilang sangat bagus. Hal tersebut dapat dibuktikan dari hasil analisis data yang menunjukkan pada prasiklus dari 20 anak dalam satu kelas, diketahui bahwa 1 Anak mendapat skor BSB (5\%), tidak ada anak mendapat skor BSH (0\%), dan 6 Anak mendapat skor MB (30\%), dan 13 Anak mendapat skor BB (65\%). Data pra siklus di atas diketahui bahwa jumlah penilaian dari 20 Anak adalah 768,75 sedangkan nilai rata-rata adalah 38,43. data siklus I dari 20 anak dalam satu kelas, diketahui bahwa 7 anak mendapat skor BSB (53\%), 13 anak mendapat skor BSH (65\%), dan tidak ada anak mendapat skor MB, dan tidak ada anak mendapat skor BB. Dari data diatas dikatahui bahwa jumlah penilaian 20 orang anak adalah 1487,5 sedangkan rataratanya adalah 74,375. Sedangkan dari data siklus II diatas dapat diketahui bahwa dari 20 anakdalam satu kelas, diketahui bahwa 20 anak mendapat skor BSB (100\%), tidak ada anak mendapat skor BSH (0\%), dan tidak ada anak mendapat skor MB (0\%), dan tidak anak mendapat skor BB (0\%). Data pra siklus di atas diketahui bahwa jumlah penilaian dari 20 anak adalah 1875 sedangkan nilai rata-rataadalah 93,75 yang dikategorikan dalam skor BSB (Berkembang Sangat Baik) sehingga sudah adanya peningkatan pada nilai rata-rata perkembangan kemampuan kerjasama anak. Ini membuktikan kerjasama anak meningkat menggunakan metode outbound pada anak kelompok A RA Muadz Bin Jabal Desa Sawah Kampar Utara.

\section{DAFTAR PUSTAKA}

Ancok, D. (2005). Outbound Management Training. Jogyakarta : UII Press.

Apriani, D. (2013). "Upaya meningkatkan kerjasama siswa dalam pembelajaran matematika melalui model pembelajaran tutor sebaya". https://scholar.google.co.id/scholar?hl=id\&as sdt=0\%2C5\&q=UPAYA++M ENINGKATKAN+PEMBELAJARAN+MATEMATIKA+MELALUI+METODE L+PEMBELAJARAN+TUTOR+SEBAYA\&btnG=\#d=ga qabs\&u=\%23p\%3 DJG8SvVybj0EJ. Diunduh 28 februari 2020.

Badiatul, M. A. (2009). Fun Out bound: Merancang Outbound yang Efektif Yogyakarta: Diva Press.

D Apriani. (2013). Meningkatkan Kemampuan Kerjasama Siswa Dengan Menggunakan Model Pembelajaran Cooperative Learning Tipe Stad Pada Materi Pesawat Sederhana di Kelas V SDN 13/ 1 MuaraBulian. http://scholar.google.co.id\&as sdt=0\%2C5\&q=upayah+meningkatkan+kerjas ama+siswa+dalam+pembelajaran+matematika+melalui+model+pembelajara n+tutor+sebaya\&btnG=\#d=gs gabs\&u=\%23p\%3DJG8SvVybj0EJ. Diunduh 28 februari 2020. 
Djamaludin, A. (2007). Outbound Management Training. Yogyakarta: UII Press Yogyakarta.

E.Mulyasa. (2010). Praktik Penelitian Tindakan Kelas. Bandung: PY Remaja RosdakaryaOffset.

Hamzah, B. U. Al. (2012). Menjadi Peneliti PTK Yang Profesional .Jakarta: Bumi Aksara.

Joko, S. O. (2006). Metode Penelitian Dalam Teori Dan Praktek. Jakarta: PT Rineka Cipta.

Latif, M, A. \& Hafidh A. (2018). Peningkatan Kemampuan Kerjasama dan Keberanian Melalui Kegiatan Outbound di RA DWP UIN Sunan Kalijaga Yogyakarta.

Musnar Indra Daulay. (2018). Meningkatkan Kemampuan Kognitif Anak dengan Permainan Ludo. Aulad: Journal on Early Childhood 1 (1), 2018

Musnar Indra Daulay. (2018). Peningkatan Kemampuan Motorik Halus Anak melalui Kegiatan Kolase Media Daun Ketepeng. Aulad: Journal on Early Childhood 1 (1), 2018

Musnar Indra Daulay. (2018). Kepuasan Orang Tua Terhadap Layanan Pendidikan Lembaga PAUD di TK Qurrota Ayun Pekanbaru. KINDERGARTEN: Journal of Islamic Early Childhood Education, Vol. 1 2018

Poerwadarminta. (2007). Kamus Besar Bahasa Indonesia. Jakarta : PN Balai.

Roestiyah N.K. (2012). Strategi Belajar Mengajar. Jakarta: Rineka Cipta.

Rudyanto \& Saputra, M.Y. (2005). Pembelajaran Kooperatif Untuk Meningkatkan Keterampilan Anak TK. Jakarta: Direktorat Pembinaan Pendidikan Tenaga Kependidikan.

Suharsimi Arikunto. (2005). Manjemen Penelitian. Jakarta: Rineka Cipta.

$$
\text { . (2006) Prosedur Penelitian Suatu Pendekatan Praktik. }
$$
Jakarta: Rineka Cipta.

Susanta, A. (2010). Outbound Profesional. Yogyakarya: Andi Offset.

Susanto, A. (2011). Perkembangan Anak Usia Dini: Pengantar Dalam Berbagai Aspeknya. Kencana. Diunduh dari: http://books.google.co.id/books/about/ Perkembangan Anak Usia Dini.html?id=0qRPDwAAQBQJ\&source=kp book description\&redir esc=y. Diunduh 28 februari 2020.

T Umar-IImiah S PIRIT, 2011-EJOURNAL. UTP. AC. ID. Diunduh dari: https://scholar.google.co.id/scholar?hl=id\&as sdt=0\%2C $5 \& \mathrm{q}=$ peningkatan +kerjasama+metode+outbound\&oq=\#d=qs qabs\&u=\%32p\%3DNA WMfii wnQJ. Diunduh 28 februari 2020.

Widiasworo E. (2017). Strategi \& Metode Mengajar Siswa di Luar Kelas (Outdoor Learning) Secara Aktif, Kreatif, Inspiratif, \& Komunikatif. Yogyakarta: ARRUZZ MEDIA. 